DOI: 10.19195/0137-1150.169.12

Data przesłania artykułu: 5.09.2017

Data akceptacji artykułu: 10.01.2018

\title{
DANUTA PYTEL-PANDEY
}

Uniwersytet Wrocławski, Polska

\section{Źródła niepowodzeń współczesnej komunikacji językowej}

Odpowiednie dać rzeczy słowo. C. K. Norwid

\section{Wprowadzenie}

W ciągu ostatniego stulecia ludzkość dokonała ogromnego postępu w rozwoju techniki, medycyny i innych dziedzin nauki, ale niektóre problemy ciągle wydają się trudne do rozwiązania, a może nawet stały się bardziej widoczne niż w przeszłości. Jednym z nich jest nieumiejętność budowania przez współczesnego człowieka właściwych relacji międzyludzkich. Może zabrzmi to trywialnie, ale przed — wydawałoby się — najprostszymi ludzkimi zachowaniami, takimi jak okazywanie życzliwości, umiejętność słuchania drugiego człowieka, prowadzenie satysfakcjonującej dla rozmówców komunikacji - wyrastają przeszkody niemal nie do pokonania. Przyczyny takiego stanu rzeczy upatrywane są między innymi w takich zjawiskach, jak:

— rosnące tempo życia;

— ukierunkowanie jednostki na siebie i własny sukces — rosnący egocentryzm i tak zwany wyścig szczurów, w którym drugi człowiek jest narzędziem/ przeszkodą, a nie partnerem;

— nadmiar informacji, których przeciętna jednostka nie jest w stanie przyjąć;

— konsumpcjonizm — dążenie do zaspokajania potrzeb materialnych jest ważniejsze niż kontakt z drugim człowiekiem;

— degradacja takich wartości, jak przyjaźń, koleżeństwo, poświęcenie, bezinteresowność. 
Współczesny człowiek często ma wszystko, tylko nie ma z kim cieszyć się $\mathrm{z}$ tego, co posiada, ponieważ nie potrafi nawiązywać i podtrzymywać trwałych relacji z innymi. Także z wymienionych powodów problem właściwego prowadzenia komunikacji, która jest podstawą wszelkich przejawów życia społecznego, stał się przedmiotem zainteresowania wielu dziedzin nauki, w tym medycyny, psychologii, socjologii i lingwistyki. W niniejszym opracowaniu chciałabym przedstawić wybrane prace dotyczące skuteczności/nieskuteczności komunikacji językowej, które wyznaczyły kierunek dalszych badań tego problemu, a następnie spróbować odpowiedzieć na pytanie „Gdzie są źródła niepowodzeń współczesnej komunikacji językowej?”. Przez niepowodzenie komunikacyjne będę tu rozumieć nieosiągnięcie przez nadawcę celu komunikacji. Przyjęta przeze mnie definicja bazuje na poglądzie Iosifa Sternina, zgodnie z którym „коммуникативная неудача - это отрицательный результат общения, такое завершение общения, когда цель общения оказывается недостигнутой”1 .

\section{Problem skuteczności/nieskuteczności komunikacji językowej w świetle wybranych badań lingwistycznych}

Na temat niepowodzeń komunikacyjnych (ros. коммуникативные неудачи, ang. miscommunication, niem. Misskommunikation), a zwłaszcza ich unikania, od połowy ubiegłego wieku powstało wiele prac popularnonaukowych o charakterze ogólnych poradników, ale też skierowanych do konkretnych grup odbiorców: osób zajmujących się zarządzaniem zasobami ludzkimi, pedagogów czy rodziców. Niezwykłą popularnością, szczególnie w Europie Zachodniej, cieszą się na przykład prace Friedemanna Schulza von Thuna: Sztuka rozmawiania. Analiza zaburzeńn ${ }^{2}$, Sztuka rozmawiania. Rozwój osobowy ${ }^{3}$, Sztuka rozmawiania. Dialog wewnętrzny ${ }^{4}$, Sztuka rozmawiania. W porozumieniu z soba i innymi-komunikacja i kompetencje społeczne ${ }^{5}$, a także praca zbiorowa Schulza von Thuna, Ingharda Langera i Reinharda Tauscha Wyrażać się zrozumiale ${ }^{6}$. Bestsellerem stał się też poradnik unikania niepowodzeń komunikacyjnych w procesie wycho-

${ }^{1}$ Cуt. za: А. Ю. Маслова, Введение в прагмалингвистику, Москва 2008, s. 113.

${ }^{2}$ F. Schulz von Thun, Sztuka rozmawiania. Analiza zaburzeń, przeł. P. Włodyga, Kraków 2001.

${ }^{3}$ F. Schulz von Thun, Sztuka rozmawiania. Rozwój osobowy, przeł. P. Włodyga, Kraków 2001.

${ }^{4}$ F. Schulz von Thun, Sztuka rozmawiania. Dialog wewnętrzny, przeł. P. Włodyga, Kraków 2001.

${ }^{5}$ F. Schulz von Thun, Sztuka rozmawiania. W porozumieniu z soba i innymi - komunikacja i kompetencje społeczne, przeł. P. Włodyga, Kraków 2006.

${ }^{6}$ F. Schulz von Thun, I. Langer, R. Tausch, Wyrażać się zrozumiale, przeł. P. Włodyga, Kraków 2004. 
wania dzieci, napisany przez duet psychologów: Adele Faber i Elaine Mazlish Jak mówić, żeby dzieci nas stuchały. Jak stuchać, żeby dzieci do nas mówity ${ }^{7}$.

Pojawiło się również wiele badań naukowych opisujących ten problem z perspektywy różnych dziedzin: filozofii, socjolingwistyki, pragmalingwistyki oraz psycholingwistyki. Chciałabym zwrócić szczególną uwagę na niektóre z tych prac. Zacznę od poglądów badaczy związanych z filozofią języka: Johna Langshawa Austina, Johna Rogersa Searle'a i Herberta Paula Grice'a, ponieważ ich przemyślenia dały początek współczesnemu podejściu do badań nad skutecznością komunikacji.

Pierwszą z przedstawianych publikacji jest Jak działać słowami twórcy teorii aktów mowy J. L. Austina, który mówi o tak zwanych niefortunnościach-niewypałach i niefortunnościach-nadużyciach ${ }^{8}$. Pojawiają się one podczas realizacji performatywnych wypowiedzi, uniemożliwiając ich skuteczne wypełnienie. W rezultacie nie udaje się osiągnąć pożądanego celu komunikacji, a więc można mówić o porażce ${ }^{9}$. Zaistnienie niefortunności skutkuje niepowodzeniem. Przed takim scenariuszem ma chronić sześć reguł Austina:

1. Musi istnieć uznana procedura konwencjonalna posiadająca pewien konwencjonalny skutek; procedura ta musi obejmować wypowiadanie pewnych słów przez pewne osoby w pewnych okolicznościach, przy czym:

2. poszczególne osoby i okoliczności w danym przypadku muszą być odpowiednie dla powołania odpowiedniej procedury, jaka została powołana.

3. Wszyscy uczestnicy muszą przeprowadzić daną procedurę zarówno poprawnie, jak też

4. w zupełności.

5. Kiedy, co zdarza się często, dana procedura jest przeznaczona do użytku dla osób, mających pewne myśli i uczucia lub do wszczynania, jako następstwa, pewnego postępowania jakiegoś uczestnika, wtedy osoba uczestnicząca, a więc powołująca daną procedurę, musi faktycznie mieć owe myśli i żywić te uczucia, a intencją uczestników musi być postępowanie w dany sposób, a ponadto

6. rzeczywiście muszą w następstwie postępować w ten sposób ${ }^{10}$.

Austin patrzy na niepowodzenia-niefortunności z perspektywy filozofii języka. Podobnie czyni jego następca i krytyk J. R. Searle, który wprowadza terminy: reguły regulatywne i reguły konstytutywne. U podstaw jego rozważań leży hipoteza, że „semantyka języka może być traktowana jako seria systemów reguł konstytutywnych i że akty illokucji są aktami dokonywanymi w zgodzie z takimi

${ }^{7}$ A. Faber, E. Mazlish, Jak mówić, żeby dzieci nas stuchaty. Jak stuchać, żeby dzieci do nas mówity, przeł. M. Więznowska, B. Horosiewicz, Poznań 2013.

8 J. L. Austin, Jak działać słowami, [w:] idem, Mówienie i poznawanie: rozprawy $i$ wykłady filozoficzne, przeł. B. Chwedeńczuk, Warszawa 1993, s. 573-598.

9 J. L. Austin pisze: ,przypadki, w których coś idzie źle, a więc dana czynność — zaślubiny, zakład, pozostawienie spadku, chrzest i różne inne — kończy się, przynajmniej w pewnej mierze, niepowodzeniem. Możemy powiedzieć, że wypowiedź jest wówczas wprawdzie nie fałszywa, lecz w ogólności nieudana" - J. L. Austin, Jak działać stowami..., s. 563.

${ }^{10}$ Ibidem, s. 563-564. 
zbiorami konstytutywnych reguł"11. Wprowadza on reguły: zawartości zdaniowej, przygotowawczą, szczerości i istotną, które powinny zostać wypełnione, aby konkretny akt illokucyjny miał właściwą moc illokucyjną ${ }^{12}$. Naruszanie reguł powoduje zaburzenie mocy aktów illokucji, co w konsekwencji prowadzi do częściowego lub całkowitego niewypełnienia intencji komunikacyjnej nadawcy i oznacza niepowodzenie komunikacyjne.

Nieco inny pogląd reprezentuje H. P. Grice. Na brak sukcesu komunikacyjnego narażają się według niego rozmówcy łamiący nadrzędną Zasadę Kooperacji i cztery maksymy:

— ilości: 1) uczyń swój udział tak informatywnym, jak jest to wymagane z punktu widzenia aktualnych celów rozmowy; 2) nie czyń swego udziału bardziej informatywnym, niż jest to wymagane;

— jakości: 1) nie mów tego, o czym sądzisz, że jest fałszem;2) nie mów tego, dla czego nie masz należytego uzasadnienia;

— odniesienia: 1) mów na temat;

— sposobu — mów zrozumiale: 1) unikaj niejasności wysławiania; 2) unikaj niejednoznaczności; 3) mów zwięźle (unikaj niepotrzebnej rozwlekłości); 4) mów w sposób uporządkowany ${ }^{13}$.

Sam autor maksym potwierdza, że przestrzeganie niektórych $\mathrm{z}$ nich jest mniej doniosłe niż innych. Najistotniejsze jest, aby:

- uczestnicy komunikacji mieli pewien wspólny bezpośredni cel, chociaż cele ostateczne mogą być zupełnie inne;

— ich udział się nawzajem zazębiał, bo jest od siebie zależny;

— łączył ich pewien rodzaj porozumienia, w myśl którego ich współdziałanie będzie kontynuowane tak długo, aż obie strony zdecydują, że trzeba je zakończyć14

Treści te są właściwie zawarte w Zasadzie Kooperacji i jeśli rozmówcy ją złamią, najprawdopodobniej poniosą porażkę komunikacyjną.

Wzorując się na postulatach badacza, będących wskazówkami dla nadawcy. mającymi pomóc mu uniknąć nieporozumień i zapewnić sukces komunikacyjny, Geoffrey Leech rozbudował i uszczegółowił maksymy Grice’a. Uznał on, że rozmówcy powinni uwzględniać dwie grupy uwarunkowań niezbędnych dla komunikacji kończącej się sukcesem:

11 J. R. Searle, Czym jest akt mowy, przeł. H. Buczyńska-Garewicz, „Pamiętnik Literacki” 1980, nr 2, s. 244.

12 J. R. Searle, Struktura czynności illokucyjnych, [w:] idem, Czynności mowy. Rozważania z filozofii języka, przeł. B. Chwedeńczuk, Warszawa 1987, s. 84-96. nr 6, s. 89.

13 H. P. Grice, Logika a konwersacja, przeł. J. Wajszczuk, „Przegląd Humanistyczny” 1977,

${ }^{14}$ Ibidem, s. 91. Na temat przestrzegania Zasady Kooperacji i reguł proponowanych przez Grice’a powstało wiele polemik. Jedną z nich jest artykuł Dariusza Galasińskiego, Czy przestrzeganie regut konwersacyjnych zawsze sprzyja udatności aktu mowy?, „Polonica” 16, 1994, s. 69-83. Reguły Grice'a są jednak bez wątpienia jednymi z najbardziej cenionych i rozpowszechnionych reguł prowadzenia satysfakcjonującej komunikacji. 
1. pierwsza grupa dotyczy organizacji samego tekstu i należą do niej: reguła poprawności gramatycznej i zrozumiałości, reguła dopasowania wypowiedzeń do kontekstu lingwistycznego, reguła ekonomiczności w konwersacji oraz reguła ekspresyjności;

2. druga grupa dotyczy zasad organizacji kontekstu interpersonalnego i należą do niej: reguła uprzejmości, reguła aprobaty rozmówcy, reguła skromności, reguła zgodności, reguła współdziałania, reguła ironii, reguła atrakcyjności treści, reguła Polyanny ${ }^{15}$.

Po przyjrzeniu się wszystkim regułom proponowanym przez Leecha widzimy, że podobnie jak Grice umieszcza on wśród zasad regułę współdziałania, będącą wyraźną analogią do Zasady Kooperacji. Chęć współdziałania wynikająca z silnej determinacji rozmówców, żeby osiągnąć cel swojej komunikacji, albo inaczej - spowodować realizację intencji komunikacyjnej, jest nadrzędną regułą, która uchroni interlokutorów przed niepowodzeniem.

Uproszczony model wolnej od porażek komunikacji, bazując także na badaniach Grice'a, podaje Robin Lakoff w artykule The logic of politeness, or minding your P's and Q's. Lingwistka włącza do badań nad udaną komunikacją element grzeczności. Jej reguły brzmią:

1. Be clear (Wyrażaj się jasno);

2. Be polite (Wyrażaj się grzecznie).

Druga reguła została rozbudowana o trzy kolejne wskazówki:

— Don't impose (Nie bądź natrętny);

- Give options (Daj możliwość wyboru);

— Be friendly (Bądź przyjazny. Stwórz partnerowi przyjazne odczucie) ${ }^{16}$.

Reguły Lakoff zbliżają się do kierunku reprezentowanego przez Penelope Brown i Stephena Levinsona. Socjopsychologiczne ujęcie komunikacji międzyludzkiej przedstawione przez Brown i Levinsona w Universals in language usage: Politeness phenomena zapoczątkowało nowe podejście do związanych z nią problemów. W nawiązaniu do badań Ervinga Goffmana ${ }^{17}$ zastosowali oni termin FACE (TWARZ) - ,the pablic self-image that every member wants to claim for himself"18, a więc twarz jako publiczny obraz samego siebie, który każda jednostka chce zachować. Unikanie porażek komunikacyjnych będzie polegało na takim prowadzeniu komunikacji między rozmówcami, aby maksymalnie zmniejszyć ryzyko powstawania tak zwanych face-threatening acts (FTAs) - 'aktów zagrażających twarzy'. $Z$ tego powodu Brown i Levinson definiują dwa rodzaje

15 Cyt. za: L. Cirko, Akceptacja w komunikowaniu się. Między preskryptywizmem a permisywizmem, Wrocław 2009, s. 88-89.

${ }^{16}$ Cyt. za E. Tomiczek, Z badań nad istota grzeczności językowej, [w:] Język a kultura, t. 6. Polska etykieta językowa, red. J. Anusiewicz, M. Marcjanik, Wrocław 1992, s. 20.

17 E. Goffman, Interaction Ritual: Essays on Face to Face Behaviors, Garden City, New York 1967.

18 P. Brown, S. Levinson, Universals in language usage: Politeness phenomena, [w:] Questions and Politeness Strategies in Social Interaction, red. E. N. Goody, Cambridge 1978, s. 66. 
twarzy: negatywną — „negative face: the basic claim to territories, personal preserves, rights to non- distraction - i.e. to freedom of action and freedom from impositin"19 i pozytywną — ,positive face: the positive consistent self — image or »personality« (crucially including the desire that this self — image be appreciated and approved of) claimed by interactants" 20 . Podczas komunikacji dochodzi do pewnego zderzenia - wzmocnienie pozytywnej twarzy rozmówcy często skutkuje osłabieniem negatywnej twarzy nadawcy i odwrotnie — naruszenie twarzy odbiorcy pozwoli zachować twarz nadawcy. Do porażki komunikacyjnej nie dojdzie, gdy poziomy osłabienia twarzy nadawcy i odbiorcy nie przekroczą akceptowalnej przez obie strony granicy. Konsekwencją tych uwarunkowań jest zachowywanie dwóch rodzajów grzeczności - negatywnej i pozytywnej - realizowanych przez odpowiednie strategie używane przez rozmówców ${ }^{21}$.

Zapobieganie niepowodzeniom komunikacyjnym to także przedmiot zainteresowania badaczy zajmujących się językiem w ujęciu socjokulturowym i socjolingwistycznym, a zwłaszcza szeroko pojętą grzecznością. Takich analiz powstało bardzo wiele i ciągle pojawiają się kolejne, ponieważ normy regulujące zachowania poszczególnych społeczeństw ewoluują wraz z nimi. Ze względu na ich ogromną ilość przywołam tylko kilka przykładów.

Wśród rusycystycznych do znanych i cenionych należą między innymi prace Natalii Formanowskiej: Русский речевой этикет. Лингвистический и методический аспекты ${ }^{22}$, Речевое взаимодействие. Коммуникация и прагматика ${ }^{23}$, Речевой этикет в русском общении. Теория и практика ${ }^{24}$, Коммуникативный контакт ${ }^{25}$; Renate Rathmayr: Pragmatik der Entschuldigungen. Vergleichende Untersuchung am Beispiel der russischen Sprache und Kultur ${ }^{26}$, Русская речь и рынок. Традиции и инновации в русском общении ${ }^{27}$ oraz Tatiany Łariny Категория вежливости и стиль коммуникаџии. Сопоставление английских и русских лингвокультурных традищий ${ }^{28}$. Spośród polskich badań chciałabym wspomnieć o pracach Eugeniusza Tomiczka: System adresatywny współczesnego języka polskiego i niemieckiego. Socjolingwistyczne stu-

19 Ibidem. s. 66.

${ }^{20}$ Ibidem.

${ }^{21}$ Ibidem, s. 96-232.

22 Н. И. Формановская, Русский речевой этикет. Лингвистический и методический аспекты, Москва 2008.

${ }^{23}$ Н. И. Формановская, Речевое взаимодействие: коммуникация и прагматика, Москва 2007.

${ }^{24}$ Н. И. Формановская, Речевой этикет в русском общении. Теория и практика, Москва 2009.

${ }^{25}$ Н. И. Формановская, Коммуникативный контакт, Москва 2012.

${ }^{26}$ R. Rathmayr, Pragmatik der Entschuldigungen. Vergleichende Untersuchung am Beispiel der russischen Sprache und Kultur, Köln-Weimar-Wien 1996.

27 Р. Ратмайр, Русская речь и рынок. Традиции и инновации в деловом и повседневном общении, Москва 2013.

28 Т. В. Ларина, Категория вежливости и стиль коммуникации. Сопоставление английских и русских лингвокультурных традиций, Москва 2009.

Slavica Wratislaviensia 169, 2019

(C) for this edition by CNS 
dium konfrontatywne ${ }^{29}$ i (we współautorstwie z Ulrichem Englem) Wie wir reden. Sprechen im deutsch - polnischen Kontrast ${ }^{30}$ oraz Małgorzaty Marcjanik: Polska grzeczność językowa ${ }^{31}$, Grzeczność w komunikacji językowej ${ }^{32}$. Z niemieckojęzycznych badań nad grzecznością warto wymienić publikację Martina Haase Respekt: Die Grammatikalisierung von Höflichkeit33 oraz pracę zbiorową wydaną pod redakcją Heinza-Helmuta Lügera zatytułowaną Höflichkeitsstile ${ }^{34}$.

Małgorzata Marcjanik mówi o demokratyzacji postaw grzecznościowych, charakterystycznej dla współczesnych zachowań językowych Polaków, oraz o przejmowaniu amerykańskiego stylu zachowania. W moim przekonaniu można rozszerzyć krąg ludzi, których one dotyczą, co najmniej do całej Europy. Do przejawów tego zjawiska należą:

— egalitaryzm grzecznościowy,

— dążenia emancypacyjne kobiet;

— dążenia do indywidualizmu w zachowaniach;

— zanikanie autorytetów;

— ekonomiczność zachowań grzecznościowych;

— utylitaryzm grzecznościowy ${ }^{35}$.

Socjolingwistyczne spojrzenie na komunikację zawsze odbywa się poprzez pryzmat socjalnego zróżnicowania jednostek i pozycji, jakie one w danym społeczeństwie zajmują. Z każdą socjalną rolą związane są pewne oczekiwania, tak zwane ekspektacje (od łac. expectation - 'oczekiwanie'), które podczas komunikacji powinny zostać wypełnione, aby komunikacja zachodziła bez przeszkód. Determinują one użycie określonych środków językowych i pozajęzykowych ${ }^{36}$. Witalij Kostomarow, Aleksiej Leontjew i Boris Schwarzkopf wyróżniają trzy rodzaje ekspektacji:

1. ekspektacje związane z sytuacją jako taką;

2. ekspektacje związane z pozycją mówiącego;

3. ekspektacje związane z charakterem wydarzenia, czyli w naszym wypad$\mathrm{ku}$ z socjalnopsychologicznymi funkcjami komunikacji językowej, z miejscem aktu językowego w ogólnym systemie działalności socjalnej grupy 37.

${ }^{29}$ E. Tomiczek, System adresatywny wspótczesnego języka polskiego i niemieckiego. Socjolingwistyczne studium konfrontatywne, Wrocław 1983.

${ }^{30}$ U. Engel, E. Tomiczek, Wie wir reden. Sprechen im deutsch - polnischen Kontrast, Wrocław-Dresden 2010.

${ }^{31}$ M. Marcjanik, Polska grzeczność językowa, Kielce 1997.

32 M. Marcjanik, Grzeczność w komunikacji językowej, Warszawa 2008.

33 M. Haase, Respekt: Die Grammatikalisierung von Höflichkeit, München-Newcastle 1994.

34 Höflichkeitsstile, red. H. H. Lüger, Frankfurt am Main 2002.

${ }^{35}$ M. Marcjanik, Grzeczność..., s. 28.

36 Por. Л. П. Крысин, Речевое общееие и соичильные роли говорящих, [w:] Социальнолингвистические исследования, red. Л. П. Крысина, Д. Н. Шмелёва, Москва 1976, s. 43.

37 Zob. В. И. Костомаров, А. А. Леонтьев, Б. С. Шварцкопф, Теория речевой деятельности и культура речи, [w:] Теория речевой деятельности, red. А. А. Леонтьева, Москва 1974, s. 306.

Slavica Wratislaviensia 169, 2019

(C) for this edition by CNS 
Wyznacznikami pozycji jednostki w społeczeństwie są: wiek, płeć, poziom wykształcenia, wykonywany zawód, zajmowane stanowisko, rodzina, sytuacja majątkowa, miejsce zamieszkania. Z pozycją socjalną związane jest wypełnianie określonych ról. Mogą one mieć charakter stały lub przejściowy. Wszyscy członkowie danej społeczności codziennie odgrywają dziesiątki ról (na przykład męża i ojca w domu, sąsiada, przechodnia, kierowcy, pacjenta, przyjaciela, pracownika lub pracodawcy, klienta w sklepie) i z każdą z nich wiązane jest inne oczekiwanie. Jeśli nie zostanie ono spełnione, może stać się przyczyną porażki komunikacyjnej. Zależność ta wygląda następująco: to, co jest prawem dla nadawcy, jednocześnie staje się obowiązkiem dla odbiorcy i odwrotnie. Zobrazować ją może następujący przykład: przychodząc do sklepu, klient oczekuje, że zostanie grzecznie obsłużony - to jego prawo związane z rolą kupującego; zadaniem ekspedienta jest grzecznie obsłużyć kupującego — to jego obowiązek jako sprzedającego. Jeśli sprzedający zawiedzie ekspektacje klienta związane z sytuacją kupna/sprzedaży dóbr, bardzo prawdopodobnie urażony klient zrezygnuje z zakupu towaru i opuści sklep - zamiar klienta poniesie klęskę i w konsekwencji towar nie zostanie zakupiony.

Rozpoczynając komunikację, interlokutorzy zawsze mają jakąś intencję/cel, który determinuje wybór odpowiednich środków, na przykład kiedy chcemy poprosić o pomoc, możemy użyć pytań: „Czy możesz...?”, „Czy mógłbyś...?”. Analiza pragmalingwistyczna wypowiedzi zajmuje się dopasowaniem najwłaściwszych środków do wyrażenia wybranej przez nadawcę intencji. Użycie nieodpowiednich sformułowań najprawdopodobniej nie przyniesie oczekiwanej reakcji odbiorcy. Renata Grzegorczykowa wyodrębniła dwa podstawowe typy intencji/ funkcji wypowiedzi: informacyjne i pozainformacyjne (sprawcze, nakłaniające, ekspresywne i kreatywne) $)^{38}$. Rozpatrywanie wypowiedzi pod kątem konwencjonalności wyrażania ich intencji przeprowadzone przez Grzegorczykową wykazało, że zasadniczo możliwe są trzy sytuacje:

1. pierwsza, kiedy zachodzi zgodność między intencją pragmatyczną i semantyczną, na przykład „Obiecuję przynieść książkę”;

2. druga, gdy zachodzi potrzeba doprecyzowania pragmatycznego intencji ogólnie sygnalizowanej przez wykładniki językowe — napis na kartce: „Przyjdź jutro!" informuje tylko o dyrektywności, a dopiero sytuacja doprecyzuje, o jaki akt mowy chodzi: rozkaz, prośbę czy może radę;

3. trzecia to niezgodność intencji wyrażonej językowo i intencji pragmatycznej. Sytuacja ta dotyczy pośrednich aktów mowy.

Dwa pierwsze przypadki mają miejsce przy bezpośrednich aktach mowy ${ }^{39}$.

${ }^{38}$ R. Grzegorczykowa, Problem funkcji języka i tekstu w świetle teorii aktów mowy, [w:] Język a kultura, t. 4. Funkcje języka i wypowiedzi, red. J. Bartmiński, R. Grzegorczykowa, Wrocław 1991, s. 23.

39 R. Grzegorczykowa, Językowe wyktadniki intencji wypowiedzi, „Biuletyn Polskiego Towarzystwa Językoznawczego" 42, 1989, s. 74-75. 
Największe zagrożenie niepowodzenia komunikacyjnego ma miejsce w wypadku trzecim, ponieważ rozmówca musi właściwie odczytać intencję nadawcy. W pośrednich aktach mowy odbiorca powinien posiadać dużą kompetencję komunikacyjną konieczną do odszyfrowania rzeczywistego celu nadawcy. W sytuacji pierwszej i drugiej rozmówca ma zadanie łatwiejsze — odbiór intencji nie jest skomplikowany, a sukces komunikacyjny zależy przede wszystkim od woli odbiorcy.

Ostatnią pracą, na którą chciałabym zwrócić uwagę w tej części, jest Gramatyka interakcji werbalnej Aleksego Awdiejewa ${ }^{40}$. Jej autor mówi o strategiach konwersacyjnych niezbędnych do osiągnięcia celu komunikacyjnego. W tym sensie badania Awdiejewa są jakby kontynuacją rozważań Grzegorczykowej. Wszystkie strategie konwersacyjne zostają podzielone na dwie grupy:

1. antagonistyczne - cele komunikacyjne uczestników konwersacji nie są zbieżne i dlatego nadawca albo stara się maksymalnie przystosować swój cel do potrzeb odbiorcy, albo usiłuje nakłonić go do przystosowania jego celu komunikacyjnego do swych potrzeb;

2. nieantagonistyczne - istnieje zbieżność celów komunikacyjnych nadawcy i odbiorcy ${ }^{41}$.

Dalszy podział strategii następuje w zależności od celów komunikacyjnych. Awdiejew wydziela cztery podstawowe grupy:

1. strategie informacyjno-weryfikacyjne;

2. strategie aksjologiczno-emotywne;

3. strategie behawioralne;

4. strategie metadyskursywne ${ }^{42}$.

Użycie strategii niedostosowanej do celu komunikacyjnego grozi niepowodzeniem.

\section{Niepowodzenia komunikacyjne - przyczyny}

W niniejszej pracy przez niepowodzenie komunikacyjne będę rozumieć nieosiągnięcie przez nadawcę celu komunikacji. We wprowadzeniu podałam, że bazuje ona na poglądzie Sternina, który uważa, że porażka komunikacyjna to negatywny rezultat komunikacji, takie jej zakończenie, w którym cel komunikacyjny nie zostanie osiągnięty. W rosyjskojęzycznej literaturze naukowej chętnie przywoływany ${ }^{43}$ jest pogląd reprezentowany przez Olgę Jermakową i Jelenę Ziemską, które uznają, że

40 A. Awdiejew, Gramatyka interakcji werbalnej, Kraków 2004.

${ }^{41}$ Ibidem, s. 71.

42 Ibidem.

43 Zob. nр. Н. И. Формановская, Речевое взаимодействие..., s. 353; А. Ю. Маслова, Введение в..., s. 113; А. Мустайоки, Причины коммуникативных неудач: попытка общей теории, „Русский язык за рубежом” 2011, nr 4, s. 76. 
Коммуникативная неудача - это полное или частичное непонимание высказывания партнёром коммуникации, т.е. неосуществление или неполное осуществление коммуникативного намерения говорящего, а также возникающий в процессе общения не предусмотренный говорящим нежелательный эмоциональный эффект: обида, раздражение, изумление ${ }^{44}$.

Jermakowa i Ziemska zaprezentowały takie podejście na początku lat dziewięćdziesiątych ubiegłego wieku. Z perspektywy kolejnych badań językoznawczych, prowadzonych szczególnie pod kątem psychologii komunikacji, stawianie znaku równości pomiędzy pełnym lub częściowym niezrozumieniem wypowiedzi przez partnera komunikacji i pełną bądź niepełną realizacją intencji komunikacyjnej nadawcy wydaje się podejściem zawężającym problem. $\mathrm{Z}$ tego powodu propozycja Sternina może być właściwszym rozwiązaniem.

\subsection{Klasyfikacje niepowodzeń komunikacyjnych}

W badaniach nad niepowodzeniami komunikacyjnymi zostały podjęte próby ich klasyfikacji, kryterium podziału były szeroko rozumiane przyczyny, na które natrafili interlokutorzy podczas komunikacji.

Jermakowa i Ziemska wyróżniły następujące grupy porażek:

- wywołane budową języka (порождаемые устройством языка);

— wywołane wszelkiego rodzaju różnicami pomiędzy rozmówcami (порождаемые различиями говорящих в каком-либо отношении);

- wywołane czynnikami pragmatycznymi (порождаемые прагматическими факторами);

- metakomunikacyjne reakcje adresata na słowa nadawcy, kiedy niezrozumienie i niezadowolenie adresata wywołuje forma wypowiedzi (метакоммуникативные реакции адресата на слова говорящего, когда непонимание и неудовольствие адресата вызывает форма речи) ${ }^{45}$.

Bardziej rozbudowaną klasyfikację proponuje Wolfgang Falkner w Verstehen. Missverstehen und Missverständnisse. Rozróżnia on:

— niepowodzenia komunikacyjne wywołane przyczynami artykulacyjnymi, audytywnymi i akustycznymi;

— niepowodzenia komunikacyjne wynikające z różnic kulturowych;

— niepowodzenia komunikacyjne spowodowane różnicami w wiedzy rozmówców;

— intencjonalne (celowe) niepowodzenia komunikacyjne;

- niepowodzenia komunikacyjne powstałe z powodu różnych oczekiwań rozmówców w stosunku do rozpatrywanego tematu rozmowy;

44 О. Н. Ермакова, Е. А. Земская, К построению типологии коммуникативных неудач (на материале естественного русского языка), [w:] Русский язык в его функиионировании. Коммуникативно- прагматический аспект, red. Е. А. Земская, Д. Н. Шмелёв, Москва 1993, s. 31.

45 Ibidem, s. 33. 
— niepowodzenia sytuacyjne powiązane z kontekstem (sytuacją) ${ }^{46}$.

Natalia Formanowska także proponuje własną klasyfikację porażek komunikacyjnych, która wyraźnie odwołuje się do socjologii, psychologii i lingwistyki. Badaczka podaje trzy grupy tych zjawisk:

— socjalno-kulturowe (социальнокультурные) — różnice pomiędzy nadawcą i odbiorcą w postrzeganiu świata;

- psycho-socjalne (психосоциальные) - na przykład różne mentalne modele fragmentów rzeczywistości, naruszenie zasad zachowania językowego, niewłaściwe odczytanie przez odbiorcę intencji nadawcy;

— językowe (собственно языковые) — na przykład użycie okazjonalizmów, niepełne zrozumienie środków gramatycznych, wieloznaczność 47 .

Jeszcze nieco inny podział proponuje Dmitrij Gudkow w Теория и практика межкультурной коммуникации, który mówi o błędach w komunikacji międzykulturowej. Zazwyczaj skutkują one niepowodzeniami komunikacyjnymi. Są to:

— błędy ,techniczne” — wynikające z nieznajomości systemu fonetycznego i graficznego języka;

— błędy „systemowe” — spowodowane niedostatecznym opanowaniem systemu znaczeń języka i zakresów ich użycia;

— błędy „dyskursywne” — powstające z powodu niewłaściwej znajomości wartości i norm kulturowych danego języka;

— błędy ,ideologiczne” — kiedy niepowodzenia komunikacyjne wynikają $\mathrm{z}$ różnych światopoglądów rozmówców ${ }^{48}$.

\section{2. Źródła niepowodzeń komunikacyjnych}

Najbardziej rozpowszechniony model komunikacji językowej zaproponowany przez Romana Jakobsona zawiera sześć czynników: nadawcę komunikatu, kontekst, komunikat, kontakt (pomiędzy nadawcą i odbiorcą), kod (wspólny dla nadawcy i odbiorcy) oraz odbiorcę ${ }^{49}$. Możemy zatem powiedzieć, że nadawca chce coś przekazać odbiorcy — jest to komunikat, który zostaje wysłany do odbiorcy przy pomocy jakiegoś kodu. W związku z tym, w określonym kontekście dochodzi do kontaktu pomiędzy nadawcą i odbiorcą. Warunkiem udanej komunikacji jest właściwe odkodowanie przez odbiorcę treści komunikatu wysłanego przez nadawcę. Każdy z czynników podanych przez Jakobsona może być źródłem zakłóceń/porażek komunikacyjnych. Nadawca może powiedzieć/napisać nie to, co zamierzał albo nie tak, jak zaplanował. W danym kontekście, podczas kontaktu pomiędzy interlokutorami odbiorca może źle albo nie wszystko usłyszeć/

46 Cyt. za: А. Мустайоки, Причины коммуникативных..., s. 76.

47 Н. И. Формановская, Речевое взаимодействие..., s. 354-361.

48 Суt. za: А. Ю. Маслова, Введение..., s. 115-116. Na wpływ błędów logicznych na skuteczność komunikacji zwraca też uwagę A. Brożek - idem, Błędy logiczne w wypowiedziach a skuteczna komunikacja, „Przegląd Humanistyczny” 2010, nr 4, s. 33-42.

${ }^{49} \mathrm{https}$ ://pl.wikipedia.org/wiki/Roman_Jakobson [dostęp: 10.07.2017]. 


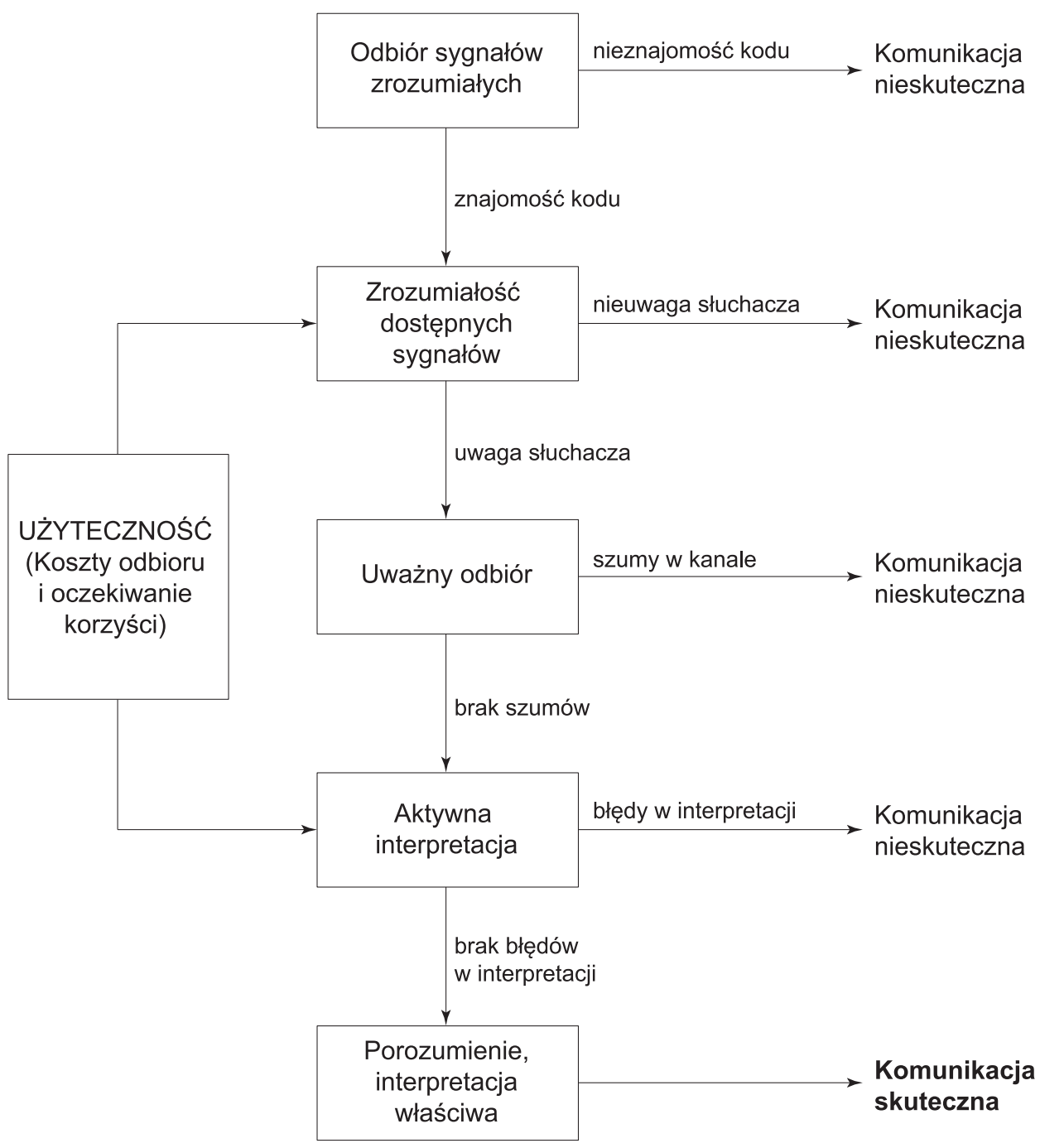

Rysunek 1. Schemat zachowań komunikacyjnych i możliwości powstawania nieporozumień Grimshawa

Źródło: Z. Nęcki, Komunikacja międzyludzka, Kraków 1996, s. 175.

przeczytać/zobaczyć, może także odkodować/zinterpretować przekaz niezgodnie $\mathrm{z}$ intencją nadawcy.

Ogólny schemat powstawania niepowodzeń komunikacyjnych zaproponował Allen D. Grimshaw, który zwrócił uwagę przede wszystkim na reakcję odbiorcy, od którego uzależniony jest efekt końcowy komunikacji — sukces lub porażka.

Zachowania interlokutorów na podstawie diagramu Grimshawa można opisać następująco: 
— do odbiorcy docierają zrozumiałe sygnały, których nie umie on odkodować, ponieważ nie zna użytego kodu, na przykład ktoś pyta: Komopbiu yac? Do słuchacza dociera poprawnie nadany sygnał, ale nie zna on języka rosyjskiego, wobec tego nie może odkodować komunikatu. Nadawca nie uzyska odpowiedzi na swoje pytanie. Komunikacja jest nieskuteczna;

— odbiorca zna kod, w którym otrzymuje przekaz, ale przez swoją nieuwagę/ skupienie się na innej czynności, nie odbiera przekazanej treści, na przykład mąż do żony oglądającej program telewizyjny: Olu, podaj mi gazetę!... Brak reakcji na prośbę - żona koncentruje się na treści programu telewizyjnego i nie słucha/ słyszy prośby. Komunikacja jest nieskuteczna;

- odbiorca próbuje odebrać sygnały nadawane w znanym mu kodzie, ale z powodu zakłóceń - szumów - nie jest to możliwe, na przykład w zatłoczonym tramwaju do koleżanki: Zosiu, czy teraz będziemy wysiadać?... Brak reakcji. Zosia nie słyszy pytania z powodu tłoku i hałasu w tramwaju. Komunikacja jest nieskuteczna;

- do odbiorcy docierają sygnały nadane w znanym mu kodzie, ale niepoprawnie są przez niego zinterpretowane, na przykład pośrednie akty mowy. Spójrzmy na następującą sytuację: w pociągu jeden z pasażerów mówi: Przeciagi szkodza zdrowiu! Pośrednia prośba o zamknięcie okna. W przypadku gdy okno nie zostanie zamknięte, a współpasażer tylko potwierdzi szkodliwość przeciągów lub w ogóle nie zareaguje, komunikacja jest nieskuteczna;

— do odbiorcy dochodzą sygnały nadane w znanym mu kodzie, nie ma szumów, następuje właściwa interpretacja odbiorcy, na przykład ktoś pyta: Która godzina? Słyszy odpowiedź: Za pięć siódma. Komunikacja jest skuteczna.

Podobnie jak Grimshaw także Arto Mustajoki, analizując niepowodzenia komunikacyjne, koncentruje swoją uwagę na osobie odbiorcy. Wychodzi on z założenia, że jedną z najważniejszych przyczyn porażek komunikacyjnych jest niewłaściwe uwzględnienie przez nadawcę osoby adresata. Zjawisko to określa jako „неадекватная реализация реципент -дизайна” ${ }^{50}$. Mustajoki nazywa trzy główne przyczyny niepowodzeń komunikacji werbalnej odnoszące się do postaci odbiorcy:

— adresat nie słyszy wypowiedzi (неслышание — non-hearing);

— adresat słyszy, ale nie słucha (неслушание — non-listenig);

— adresat słyszy nie tak, nie to, co przekazuje nadawca (mishearing) ${ }^{51}$.

Dorota Mihułka i Krystyna Mihułka patrzą na niepowodzenia komunikacyjne z perspektywy interkulturowej i podają płaszczyzny, na których może do nich dochodzić. Są to:

— kompetencja językowa;

— treść;

— realizacja;

50 А. Мустайоки, Причины коммуникативных..., s. 77.

51 Ibidem, s. 79. 
— komunikacja niewerbalna ${ }^{52}$.

Wnikliwą analizę trudności w komunikacji, które mogą być przyczyną niepowodzeń komunikacyjnych podaje Zbigniew Nęcki w książce Komunikacja międzyludzka. Wyróżnia on następujące rodzaje trudności:

1. wynikające z treści komunikatu;

2. spowodowane zakłóceniami procesu komunikowania;

3. mające swe źródło w cechach zachowań konwersacyjnych poszczególnych rozmówców ${ }^{53}$.

Po analizie przedstawionych badań oraz na podstawie własnych obserwacji sądzę, że porażki komunikacyjne, mające miejsce podczas komunikacji międzyludzkiej, powstają na podłożach o charakterze:

1. KULTUROWYM - rozmówcy/jeden z rozmówców przejawia niewłaściwy stosunek do drugiego człowieka łamiąc:

- ugruntowaną wielowiekową tradycją normę kulturową;

- obrażając uczucia związane z wyznawaną religią, światopoglądem, rodzajem okazywanego respektu należnego w danej kulturze każdemu człowiekowi;

2. SOCJOLINGWISTYCZNYM - nieprzestrzeganie przez rozmówców/ jednego z rozmówców norm socjolingwistycznych warunkujących użycie środków językowych w zależności od wieku, płci, statusu społecznego, rodzaju łączących ich zależności: przełożony-podwładny, starszy-młodszy, rodzice-dzieci, rodzaju kontaktu (oficjalny, nieoficjalny), obecności świadków - komunikacja bez świadków itd.;

3. PSYCHOLINGWISTYCZNYM - naruszanie dopuszczalnego/akceptowalnego poziomu emocjonalności wypowiedzi, ingerowanie w osobiste życie/ sprawy/problemy rozmówcy, próby manipulacji jego osobą, szantaż, a także wywoływanie celowo lub niechcący innych negatywnych emocji itp.;

4. PRAGMALINGWISTYCZNYM — dobór środków językowych nieodpowiedni, z pragmatycznego punktu widzenia, do danej sytuacji komunikacyjnej;

5. LINGWISTYCZNYM - użycie podczas komunikacji niepoprawnych językowo konstrukcji semantycznych lub gramatycznych;

6. INTELEKTUALNYM - zbyt niski poziom wiedzy uniemożliwiający uniknięcie porażek komunikacyjnych podczas rozmowy na określone tematy;

7. MEDYCZNYM — brak możliwości prowadzenia skutecznej komunikacji z powodów medycznych, na przykład: ograniczenie umysłowe, atak jakiejś choroby podczas aktu komunikacji.

Wszystkie podane źródła porażek, poza medycznymi, są wynikiem niedostatecznej kompetencji komunikacyjnej rozmówców, która warunkuje poprawne/

52 D. Mihułka, K. Mihułka, Niepowodzenia komunikacyjne w perspektywie interkulturowejimplikacje glottodydaktyczne, „Linguodidactica” 19, 2015, s. 143-153. O znaczeniu kompetencji komunikacyjnej w kontaktach językowych zob. też K. Pisarkowa, Pragmatyczny składnik kompetencji językowej, „Polonica” 1, 1975, s. 7-18; A. Piotrowski, O pojęciu kompetencji komunikatywnej, [w:] Zagadnienia socjo- i psycholingwistyki, red. A. Schaff, Wrocław 1980, s. 91-109.

53 Z. Nęcki, Komunikacja międzyludzka, Kraków 1996, s. 183-210. 
właściwe społeczne zachowania językowe każdej jednostki. Według Della Hymesa na kompetencję komunikacyjną składają się cztery komponenty: potencjał systemowy, wykonalność, występowanie i odpowiedniość. Stanisław Grabias przedstawia je w formie pytań, które powinien zadać sobie nadawca, budując wypowiedź, jeżeli potrafi dać na nie odpowiedź (czyni to zwykle nieświadomie) to znaczy, że posiada odpowiednią kompetencję komunikacyjną. Są to następujące pytania:

— czy wypowiedź jest możliwa w danym systemie językowym (potencjał systemowy)?

— czy jest ona możliwa ze względu na psychiczną i społeczną sytuację mówiącego (wykonalność)?

— czy i w jakim stopniu jest społecznie realizowana (występowanie)?

- czy i w jakim stopniu jest w danym kontekście społecznym skuteczna (odpowiedniość) $^{54}$ ?

Posiadanie właściwej kompetencji komunikacyjnej to pierwszy czynnik pozwalający uniknąć niepowodzenia komunikacyjnego.

Drugim, po kompetencji komunikacyjnej, powodem powstania porażki komunikacyjnej jest brak dostatecznie silnej determinacji rozmówców do prowadzenia konwersacji. Jeśli nawet komunikacja zaistnieje, nie będzie kontynuowana i ostatecznie nie przyniesie oczekiwanych rezultatów, czyli dojdzie do porażki. Chęć współpracy z rozmówcą i podejmowanie niezbędnego wysiłku do prowadzenia komunikacji, to nic innego jak nadrzędna Zasada Kooperacji H. P. Grice’a. Brak chęci kooperacji ze strony rozmówców oznacza niepowodzenie komunikacyjne.

Trzecim czynnikiem powodującym dążenie rozmówców do tego, żeby komunikacja nie zakończyła się porażką, jest ich subiektywna ocena korzyści, jakie mogą mieć z pozytywnego jej zakończenia. Inaczej mówiąc, im większy potencjalny zysk nadawcy i odbiorcy (albo tylko jednego z nich) jaki może przynieść uniknięcie nieporozumienia komunikacyjnego, tym chętniej będą oni/on ponosić różne koszty/straty (na przykład pozwolą na częściowe, a nawet całkowite zniszczenie swojej twarzy), żeby osiągnąć cel. Można zaryzykować twierdzenie, że wartość zysku jest wprost proporcjonalna do gotowości podejmowania starań, aby nie doszło do porażki komunikacyjnej. Im mniejszy zysk, tym mniejsza chęć do ustępstw na korzyść rozmówcy i tym bardziej prawdopodobna porażka.

\section{Podsumowanie}

Rosnące od połowy ubiegłego stulecia zainteresowanie komunikacją językową spowodowało powstanie wielu prac poświęconych jej skuteczności. Niepowodzenia komunikacyjne mają związek z powstawaniem nieporozumień na

${ }^{54}$ S. Grabias, Kompetencja językowa a kompetencja komunikacyjna, [w:] idem, Język w zachowaniach społecznych, Lublin 1997, s. 37. 
linii nadawca-odbiorca. Niniejsze opracowanie jest próbą przeglądu wybranych analiz, które nadały kierunek późniejszym badaniom lingwistycznym poświęconym tym zagadnieniom. Podane zostały warunki skutecznej komunikacji, klasyfikacje niepowodzeń komunikacyjnych, a także zwrócono uwagę na przyczyny ich powstawania.

Po przeprowadzeniu analizy można wyłonić trzy podstawowe źródła niepowodzeń komunikacji międzyludzkiej. Należą do nich:

— brak odpowiedniej kompetencji językowej,

— niestosowanie Zasady Kooperacji Grice’a

— niska wartość komunikacji — w subiektywnej ocenie rozmówców (unikanie sytuacji grożących niepowodzeniem komunikacyjnym nie przyniesie odpowiedniej korzyści).

Powody drugi i trzeci mogą być od siebie uzależnione: znikomy poziomem korzyści, jaki przyniesie komunikacja, może powodować niechęć interlokutorów do kooperacji.

\section{Bibliografia}

Austin J. L., Jak działać słowami, [w:] idem, Mówienie i poznawanie. Rozprawy i wykłady filozoficzne, przeł. B. Chwedeńczuk, Warszawa 1993, s. 545-708.

Awdiejew A., Gramatyka interakcji werbalnej, Kraków 2004.

Brown P., Levinson S., Universals in language usage: Politeness phenomena, [w:] Questions and Politeness Strategies in Social Interaction, red. E. N. Goody, Cambridge 1978, s. 56-289.

Brożek A., Błędy logiczne w wypowiedziach a skuteczna komunikacja, „Przegląd Humanistyczny" 2010, nr 4, s. 33-42.

Cirko L., Akceptacja w komunikowaniu się. Między preskryptywizmem a permisywizmem, Wrocław 2009.

Engel U., Tomiczek E., Wie wir reden. Sprechen im deutsch - polnischen Kontrast, Wrocław-Dresden 2010.

Ermakova O. N., Zemskaâ E. A., K postroeniû tipologii kommunikativnyh neudač (na materiale estestvennogo russkogo dialoga), [w:] Russkij âzyk v ego funkcionirovanii. Kommunikativno-pragmatičeskij aspekt, red. E. A. Zemskaâ, D. N. Šmelëv, Moskva 1993, s. 30-64.

Faber A., Mazlish E., Jak mówić, żeby dzieci nas stuchały. Jak stuchać, żeby dzieci do nas mówity, przeł. M. Więznowska, B. Horosiewicz, Poznań 2013.

Formanovskâ̂ N. I., Kommunikativnyj kontakt, Moskva 2012.

Formanovskaâ N. I., Rečevoe vzaimodejstvie: kommunikaciâ i pragmatika, Moskva 2007.

Formanovskaâ N. I., Rečevoj ètiket v russkom obŝenii. Teoriâ i praktika, Moskva 2009.

Formanovskaâ N. I., Russkij rečevoj ètiket. Lingvističeskij i metodičeskij aspekty, Moskva 2008.

Galasiński D., Czy przestrzeganie reguł konwersacyjnych zawsze sprzyja udatności aktu mowy?, „Polonica” 16, 1994, s. 69-83.

Goffman E., Interaction Ritual: Essays on Face to Face Behaviors, Garden City, New York 1967.

Grabias S., Kompetencja językowa a kompetencja komunikacyjna, [w:] idem, Język w zachowaniach społecznych, Lublin 1997, s. 33-39.

Grice H. P., Logika i konwersacja, przeł. J. Wajszczuk, „Przegląd Humanistyczny” 1977, nr 6, s. 85-99.

Grzegorczykowa R., Językowe wykładniki intencji wypowiedzi, „Biuletyn Polskiego Towarzystwa Językoznawczego" 42, 1989, s. 68-78. 
Grzegorczykowa R., Problem funkcji języka i tekstu w świetle teorii aktów mowy, [w:] Język a kultura, t. 4. Funkcje języka i wypowiedzi, red. J. Bartmiński, R. Grzegorczykowa, Wrocław 1991, s. 11-28.

Gudkov D. B., Teoriâ i praktika mežkul'turnoj kommunikacii, Moskva 2003.

Haase M., Respekt: Die Grammatikalisierung von Höflichkeit, München-Newcastle 1994.

Höflichkeitsstile, red. H. H. Lüger, Frankfurt am Main 2002.

Kostomarov V. I., Leont'ev A. A., Švarckopf B. S., Teoriâ rečevoj deâtel'nosti i kul'tura reči, [w:] Teoriâ rečevoj deâtel'nosti, red. A. A. Leont'eva, Moskva 1974, s. 300-311.

Krysin L. P., Rečevoe obŝenie i social'nye roli govorâsih, [w:] Social'no-lingvističeskie issledovaniâ, red. L. P. Krysin, D. N. Šmelëv, Moskva 1976, s. 42-52.

Larina T. V., Kategoriâ vežlivosti i stil' kommunikacii.Sopostavlenie anglijskih i russkih lingvokul'turnyh tradicij, Moskva 2009.

Marcjanik M., Grzeczność w komunikacji językowej, Warszawa 2008.

Marcjanik M., Polska grzeczność językowa, Kielce 1997.

Maslova A. Û., Vvedenie v pragmalingvistiku, Moskva 2008.

Mihułka D., Mihułka K., Niepowodzenia komunikacyjne w perspektywie interkulturowej - implikacje glottodydaktyczne, „Linguodidactica” 19, 2015, s. 141-156.

Mustajoki A., Pričiny kommunikativnyh neudač, „Russkij Âzyk za Rubežom” 2011, nr 4, s. 76-86.

Nęcki Z., Komunikacja międzyludzka, Kraków 1996.

Piotrowski A., O pojęciu kompetencji komunikatywnej, [w:] Zagadnienia socjo- i psycholingwisty$k i$, red. A. Schaff, Wrocław 1980, s. 91-109.

Pisarkowa K., Pragmatyczny sktadnik kompetencji językowej, „Polonica” 1, 1975, s. 7-18.

Ratmajr R., Russkaâ reč' i rynok. Tradicii i innovacii v delovom i povsednevnom obsenii, Moskva 2013.

Rathmayr R., Pragmatik der Entschuldigungen. Vergleichende Untersuchung am Beispiel der russischen Sprache und Kultur, Köln-Weimar-Wien 1996.

Searle J. R., Czym jest akt mowy, przeł. H. Buczyńska-Garewicz, „Pamiętnik Literacki” 1980, nr 2, s. 241-248.

Searle J. R., Struktura czynności illokucyjnych, [w:] idem, Czynności mowy. Rozważania z filozofii języka, przeł. B. Chwedeńczuk, Warszawa 1987, s. 74-96.

Schulz von Thun F., Sztuka rozmawiania. Analiza zaburzeń, przeł. P. Włodyga, Kraków 2001.

Schulz von Thun F., Sztuka rozmawiania. Dialog wewnętrzny, przeł. P. Włodyga, Kraków 2002.

Schulz von Thun F., Sztuka rozmawiania. Rozwój osobowy, przeł. P. Włodyga, Kraków 2001.

Schulz von Thun F., Sztuka rozmawiania. W porozumieniu z soba i innymi - komunikacja i kompetencje społeczne, przeł. P. Włodyga, Kraków 2006.

Schulz von Thun F., Langner I., Tausch R., Wyrażać się zrozumiale, przeł. P. Włodyga, Kraków 2004

Tomiczek E., System adresatywny współczesnego języka polskiego i niemieckiego. Socjolingwistyczne studium konfrontatywne, Wrocław 1983.

Tomiczek E., Z badań nad istota grzeczności językowej, [w:] Język a kultura, t. 6. Polska etykieta językowa, red. J. Anusiewicz, M. Marcjanik, Wrocław 1992, s. 15-25.

\section{Źródła internetowe}

https://pl.wikipedia.org/wiki/Roman_Jakobson. 


\section{Sources of failure of modern linguistic communication}

Summary

In this paper the author presents selected papers devoted to the conditions of effective communication, classifications of communication failures given by various researchers, and sources of communication failures. The most important causes of communication failures are:

— lack of communication competence of interlocutors;

— failure to comply with H.P. Grice's Principles of Co-operation;

- subjective assessment of interlocutors on the lack of benefits from avoiding communication failures.

Keywords: communication, effective communication, miscommunication

\section{Источники коммуникативных неудач в современной коммуникации}

Резюме

В статье автор представил обзор избранных работ, посвящённых условиям успешной коммуникации, классификации коммуникативных неудач разных исследователей и назвал причины коммуникативных неудач в современной коммуникации. По мнению автора, к ним прежде всего принадлежат:

- недостаток коммуникативной компетенции;

- несоблюдение принципа кооперации Г. П. Грайса;

- субъективная оценка собеседников, которая говорит об отсутствии пользы от общения, если они будут избегать коммуникативных неудач.

Ключевые слова: коммуникация, коммуникативный успех, коммуникативная неудача 